\section{Journal of Energy \&. \\ Environmental Sciences}

Vol. 4, $\mathrm{N}^{\circ}$ 2, 2020

\title{
Decrease in total hardness and amount of chlorides present in well water: influence of the aquatic plants of Phragmites australis and Lemna minor [Disminución de dureza total y cantidad de cloruros presentes en las aguas de pozos: influencia de las plantas acuáticas de Phragmites australis y Lemna minor]
}

Lourdes E.Saavedra ${ }^{a}$,Hans R. Portilla ${ }^{b}$, Aldo R. Castillob, Cesar P. Arevalob, Luis W. Aguilarb

a Escuela de Ingenieria de Materiales, Universidad Nacional de Trujillo - Av Juan Pablo s/n - Trujillo, Peru

${ }^{\mathrm{b}}$ Escuela de Ingenieria de Metalurgica, Universidad Nacional de Trujillo - Av Juan Pablo s/n - Trujillo, Peru

Received: 20 November 2020; Accepted: 02 December 2020; Published: 30 December 2020

Resumen

El objetivo del presente trabajo fue evaluar la influencia de las plantas acuáticas Phragmites australis (carrizo) y Lemna minor (lenteja de agua) en la reducción de la dureza total y cloruros presentes en las aguas de los pozos de Huanchaquito- Trujillo, utilizados por los habitantes para regar cultivos y autoconsumo, afectando su salud y teniendo baja producción en sus campos. Las plantas acuáticas utilizadas para el tratamiento de agua de pozo, según antecedentes, tienen un alto rendimiento en absorción de sal lo que ha permitido disminuir la cantidad de Cloruros y dureza presentes en las aguas del pozo de Huanchaquito cada 15 días durante 8 meses. Los datos obtenidos en los análisis de las muestras iniciales fueron: Con respecto a la dureza 542,7 ppm; Cantidad de $\mathrm{Cl} 300,7 \mathrm{ppm}$. Luego de que los datos promedio obtenidos para la dureza fueron de 502,4 ppm con Lemna minor solo 537,6ppm, con Phragmites australis solo y 489,8 ppm con Lemna minor y Phragmites australis, En cuanto a los resultados de cloruros tenemos: 296, 9 ppm solo con Lemna minor, 248,8 ppm solo con Phragmites australis y 233,8 ppm con Lemna minor y Phragmites australis

Palabras clave: Phragmites australis, Lemna minor, dureza total, Cloruros.

\begin{abstract}
The objective of present work was evaluating the influence Phragmites australis (common reed) and Lemna minor (duckweed) aquatic plants in the reduction of total hardness and chlorides present in the waters of wells of Huanchaquito- Trujillo. They are used by the inhabitants to irrigate crops and own consumption, affecting their health and having low production in their fields. The aquatic plants used for the treatment of well water, according to background, have a high yield in salt absorption which has allowed to decrease the amount of Chlorides and hardness present at the well's waters of Huanchaquito every 15 days for 8 months. The data obtained in the analyses of the initial samples were: With respect to hardness $542,7 \mathrm{ppm}$; Cl- amount $300,7 \mathrm{ppm}$. After the average data obtained for the hardness were of 502,4 ppm with Lemna minor only 537,6ppm, with Phragmites australis only and 489,8 ppm with Lemna minor and Phragmites australis, In terms of the results of chlorides we have: 296,9 ppm with Lemna minor only, 248,8 ppm with Phragmites australis only and 233,8ppm with Lemna minor and Phragmites australis.
\end{abstract}

Keywords: Phragmites australis, Lemna minor, Total hardness, Chlorides 


\section{Journal of Energy \& Environmental Sciences}

Vol. 4, $\mathbf{N}^{\circ} 2,2020$

\section{Introduction}

Water treatment systems with aquatic plants are an efficient and economical alternative for the treatment of wastewater, wells, water with pollutants, etc. Among these types of plants are the Lemna minor abundant in the district of Huanchaco and Phragmites australis which presents characteristics of growth adaptability in any area around $25^{\circ} \mathrm{C}$ (Arroyave, 2004).

One of the main problems nowadays is the corrosion that occurs in the pipes due to the hardness of the water, but it is not the same electrical appliances or water pipes with the human body, due to the consumption of the population of this type of water is harmful to health. According to the WHO (2020), some 785 million people around the world do not have access to clean sources of drinking water. The climate crisis is making this situation worse. Salt water, which makes up about $97 \%$ of our planet's water, is a huge untapped resource. Solutions are urgently needed to make it fit and safe. Therefore, in this work the chloride ion is detailed, it is one of the inorganic ions found in greater quantity in natural, waste and treated wastewater, its presence is necessary in drinking water. In drinking water, the chalky taste produced by the concentration of chlorides is variable, in some waters containing $25 \mathrm{mg} \mathrm{Cl}$ / L the bitter taste of chlorine can be detected. On the other hand, it may be absent in waters containing up to $1 \mathrm{~g} \mathrm{Cl}-/ \mathrm{L}$ when the predominant cations are calcium and magnesium (Ordoñez, 2011). A high content of chlorides can damage metallic structures and even prevent the growth of flora. High concentrations of chloride in water for irrigation in agricultural fields deteriorate crops, importantly the quality of the soil.

This investigation was conducted based on the following background:

The concentrations of tetracycline (TC) and degradation products were determined in the roots, stems and leaves of the plants, resulting in the plants of $P$. australis uptake TC and degradation products. The decreasing order of $P$. australis uptake was determined as ETC $>$ TC $>$ EATC $>$ ATC. (Topal, 2015). Both road drainage rainwater and duckweed (Lemna minor L.) were sampled and metals $\mathrm{Cr}, \mathrm{Mn}, \mathrm{Cu}$ and $\mathrm{Zn}$ were analyzed. This approach at the micrometric level allows a better understanding of the elemental tissue partition in this biomonitoring organism (Brito et al, 2013). The study was divided into two phases, with the following treatments: phase I with a) tap water, b) tap water + P. australis, c) ARS; phase II with a) ARS + CLT (0.29 mg/L), b) ARS + CLT (2.18 $\mathrm{mg} / \mathrm{L})$, c) CLT $(0.29 \mathrm{mg} / \mathrm{L})$, d) CLT $(2.18 \mathrm{mg} / \mathrm{L})$. Each experiment was done in duplicate. The influence of the variables relative humidity $(R H)$, solar radiation $(R s)$, ambient temperature $(T)$, barometric pressure (PB), evaporation and potential evapotranspiration (ETo) on the respiration frequency of $P$. australis was analyzed. No significant differences were found in the respiratory rate of $P$. australis $(p<0.05)$ with tap water and ARS during the phase I experiments; The same was found for all the experiments of the phase, concluding that the CLT pesticide affects the respiratory rate of $P$. australis (Serna and Casas, 2012).

Water treatment is carried out using artificial wetlands built with floating macrophytes, floating leaf macrophytes, submerged macrophytes and emergent macrophytes (Arias et al., 2003). Wetlands physically fix pollutants from the contact surface with roots, stones, soil, among others, using the aquatic plant Lemna minor $L$, where through biological and chemical processes they transform them into nutrients for microphites with a low elimination of pollutants (Mogollón, 2005). The efficiency of aquatic plants was evaluated, resulting in the most effective Lemna minor> Pistia Stratoides> Eichhorna Crassipes (Cupe and Portocarrero, 2009). Applications of wastewater treatment with aquatic plants to treat effluents from industrial, mining, agricultural and domestic activities (Montano, J.J; Sandoval, M., 2005).

Floating microphytes have proven to be efficient in the remediation of waters with nutrient content, organic matter and toxic substances such as arsenic, zinc, cadmium, copper, lead, chromium, and mercury (Martelo, 2012). It is proposed to institutionalize instruments that incorporate the environmental variable (Rodríguez, 2010). The most important sources of pollution are made 


\section{Journal of Energy \&. Environmental Sciences}

Vol. 4, $\mathbf{N}^{\circ} 2,2020$

known, it constitutes industrial and domestic discharges causing a strong impact on the receiving environment (the sea) (Guillen et al, 1978).

\section{Materials and Methods}

The procedure was carried out, as described below:

\subsection{Procedure to create Artificial Wetland:}

- The best Lemna minor seeds and Phragmites australis buds were selected, transferring them into $35 \mathrm{~cm}$ deep jars for 1 day.

- Lemna minor plants and Phragmites australis buds were prepared.

- Make glass fish tanks, a small layer of soil of approximately $2 \mathrm{~cm}$ was placed as a base.

- The layer was covered with Tecnopor (the Tecnopor must have as many holes as there are Phragmites plants to be transplanted) (Menéndez, 2005).

- The technopor was covered with sand and small gravel at a height of approximately $3 \mathrm{~cm}$, be careful to leave the holes for transplanting the Phragmites.

- Phragmites were transplanted into the holes from the aforementioned procedure.

- The fish tank was filled with well water (slowly on one side of the glass walls), let it rest for 1 hour (Bushmann, 2001).

- Lemna minor was placed on the surface of the well water of the fish tank.

- Finally, the same procedure was done for the Phragmites alone and for the Lemna minor alone, both with well water samples.

\subsection{Procedure to calculate the total Hardness of Well water:}

- According to Rodríguez, S. (2010), $25 \mathrm{~mL}$ of water sample is taken in the Erlenmeyer flask.

- Then $10 \mathrm{~mL}$ of buffer solution were added.

- A pinch of eriochrome black T (ENT) was added, showing a purple color.

- Titrated with $0.01 \mathrm{M}$ EDTA solution (disodium salt), until a blue color was appreciated.

- Reactions:

$$
\begin{aligned}
& \mathrm{Ca}^{2+}+\mathrm{Mg}^{2+}+\text { Buffer pH10------->Ca}{ }^{2+}+\mathrm{Mg}^{2+}+\text { ENT------->[Ca-Mg--ENT] } \\
& \text { Purple complex } \\
& \text { [Ca-Mg--ENT] + EDTA ------------>[Ca-Mg--EDTA] + ENT } \\
& \text { Blue color }
\end{aligned}
$$

Calculus:

$$
D T(p p m)=\frac{M_{E D T A} X V_{E D T A} X 1000}{V_{S A M P L E}}
$$

Where:

$M_{\text {EDTA }}=0,01 \mathrm{M}$

$\mathrm{V}_{\mathrm{EDTA}} \quad=$ Volume of EDTA expense.

$\mathrm{V}_{\text {MUESTRA }}=25 \mathrm{~mL}$ (volume of water for analysis) 


\section{Journal of Energy \&. Environmental Sciences}

Vol. 4, $\mathrm{N}^{\circ} 2,2020$

\subsection{Procedure to calculate the amount of $\mathrm{Cl}-$ by Mohr's method:}

- $10 \mathrm{~mL}$ of well water sample was measured with a pipette and transferred to a $250 \mathrm{~mL}$ Erlenmeyer flask.

- Dilute it in $50 \mathrm{~mL}$ of distilled water and observe the turn.

- 3 to 4 drops of $5 \% \mathrm{~K} 2 \mathrm{CrO} 4$ were added (Escutia, 2012).

- Adjust the pH to a range of $6.3-10.5$, that is, if the sample is less than 6.3, make it alkaline with sodium carbonate ( $\mathrm{NaHCO} 3$ ), but if it is greater than 10.5 , add acetic acid $(\mathrm{CH} 3 \mathrm{COOH})$.

- Titrate the flask sample with $0.1 \mathrm{~N}$ silver nitrate (AgNO3) until it turns red or pink (Skoog et al., 1995).

- The expenditure volume of $\mathrm{AgNO} 30.1 \mathrm{~N}$ was recorded.

- Reactions:

$\mathrm{Cl}^{-}+\mathrm{Ag}^{+} \rightarrow \mathrm{AgCl} \downarrow$ (White Precipitate)

$\mathrm{CrO}_{4}=+2 \mathrm{Ag}^{+} \rightarrow \mathrm{Ag}_{2} \mathrm{CrO}_{4} \downarrow$ (Brick red precipitate)

Calculus:

$$
C l^{-1}(p p m)=\frac{V_{A g N O 3} \times V_{N A g N O 3} \times P_{e q u i} C l \times 1000}{V_{\text {sample }}}
$$

Where:

$\mathrm{NAgNO}_{3}=0,1 \mathrm{M}$ solution of $\mathrm{AgNO}_{3}$

$\mathrm{VAgNO}_{3}=$ expenditure volume of solution $\mathrm{AgNO}_{3}$

$\mathrm{P}$ equiCl = Equivalent weight of $\mathrm{Cl}=35.5 / 1$

$\mathrm{V}_{\text {sample }}=$ water volume for analysis

\subsection{Procedure for calculating the removal percentage}

- To calculate the removal percentage, the initial and final results are replaced in the following formula:

$$
\% \text { Removal }=\frac{(\text { Initial value }- \text { Final value }}{\text { Initial value }}
$$

\section{Results}

Table 1 shows the initial values of the characterization of the well water of the Huanchaquito Alto district with $\mathrm{Cl}$ - and Hardness presence above the MPL (Maximum Permissible Limits), with which the research work began; treated with the Lemna minor aquatic plant, monitored every 15 days of treatment. 


\section{Journal of Energy \&. Environmental Sciences}

Vol. 4, $\mathbf{N}^{\circ} 2,2020$

Copyright @ 2020, CINCADER.

ISSN 2523-0905

DOI: https://doi.org/10.32829/eesj.v4i2.199
A publication of

\section{CINCADER}

Centre of Research and Training for

Regional Development

Online at www.journals.cincader.org

Table 1. Chlorine concentrations and Hardness as a function of Lemna minor plant.

\begin{tabular}{|c|c|c|c|c|}
\hline Sample & $\begin{array}{l}\text { Aquatic } \\
\text { plant }\end{array}$ & Time (days) & $\begin{array}{c}\text { Total hardness } \\
\text { (ppm) }\end{array}$ & $\mathrm{Cl}^{-}(\mathrm{ppm})$ \\
\hline Initial & $\begin{array}{c}\text { Lemna } \\
\text { minor }\end{array}$ & 0 & 542,7 & 300,7 \\
\hline \multirow{3}{*}{ Sample 1} & \multirow{3}{*}{$\begin{array}{l}\text { Lemna } \\
\text { minor }\end{array}$} & \multirow{3}{*}{15} & 541,3 & 300,1 \\
\hline & & & 542,5 & 299,8 \\
\hline & & & 540,8 & 300,0 \\
\hline \multirow{3}{*}{ Sample 2} & \multirow{3}{*}{$\begin{array}{l}\text { Lemna } \\
\text { minor }\end{array}$} & \multirow{3}{*}{30} & 532,6 & 298,2 \\
\hline & & & 533,1 & 298,1 \\
\hline & & & 533,6 & 299,1 \\
\hline \multirow{3}{*}{ Sample 3} & \multirow{3}{*}{$\begin{array}{l}\text { Lemna } \\
\text { minor }\end{array}$} & \multirow{3}{*}{45} & 510,6 & 298,0 \\
\hline & & & 510,9 & 297,1 \\
\hline & & & 509,0 & 297,6 \\
\hline \multirow{3}{*}{ Sample 4} & \multirow{3}{*}{$\begin{array}{l}\text { Lemna } \\
\text { minor }\end{array}$} & \multirow{3}{*}{60} & 502,7 & 297,2 \\
\hline & & & 502,5 & 296,4 \\
\hline & & & 502,1 & 297,1 \\
\hline
\end{tabular}

Table 1 shows a initial sample ( 0 days of exposure with Lemna minor) of water obtained from the wells of Huanchaco to which analyzes were carried out obtaining a result of $542.7 \mathrm{ppm}$ of total hardness and $300.7 \mathrm{ppm}$ of quantity of Chlorides present in these waters, a fact that shows us high levels of contamination, that same standard sample is subjected to 15 days under the influence of the Lemna plant.

Minor (sample 1), which shows 541.3ppm; 542.5ppm; 540.8ppm of total hardness and $300.1 \mathrm{ppm}$; 299.8ppm; 300ppm of amount of chlorides, likewise after 30 days of this same sample under the influence of Lemna minor, a significant decrease in these concentrations of total hardness and amount of chlorides is observed, with results of $532.6 \mathrm{ppm} ; 533.1 \mathrm{ppm}$ and $533.6 \mathrm{ppm}$ of total hardness and 298.2ppm 298.1ppm 299.1ppm of amount of chlorides, in the following samples the results obtained for 45 and 60 days the decrease in total hardness and amount of chlorides is much lower than the initial one, such that the percentage of removal of total hardness and amount of chlorides is evidenced as follows:

Removal to hardness: \% Removal $=(542,7-502,1) / 542,7 \times 100=7,5 \%$

Removal to Cl-: \% Removal $=(300,7-297,1) / 300,7 \times 100=1,2 \%$

Table 2. Chlorine concentrations and Hardness as a function of Phragmites australis plant.

\begin{tabular}{ccccc}
\hline Sample & $\begin{array}{c}\text { Aquatic } \\
\text { plant }\end{array}$ & Time (days) & $\begin{array}{c}\text { Total hardness } \\
\text { (ppm) }\end{array}$ & Cl (ppm) \\
\hline \multirow{2}{*}{ Initial } & $\begin{array}{c}\text { Phragmites } \\
\text { australis }\end{array}$ & 0 & 542,7 & 300,7 \\
\hline \multirow{2}{*}{ Sample 1 } & $\begin{array}{c}\text { Phragmites } \\
\text { australis }\end{array}$ & \multirow{2}{*}{15} & 542,4 & 289,0 \\
& & & 542,1 & 288,7
\end{tabular}




\section{Journal of Energy \&. Environmental Sciences}

Vol. 4, $\mathbf{N}^{\circ}$ 2, 2020

\begin{tabular}{lcccc} 
& & & 542,3 & 287,5 \\
\hline \multirow{3}{*}{ Sample 2 } & Phragmites & \multirow{2}{*}{30} & 541,6 & 267,3 \\
& australis & & 541,9 & 268,5 \\
& & & 541,5 & 266,9 \\
\hline \multirow{3}{*}{ Sample 3 } & \multirow{2}{*}{45} & 540,3 & 253,2 \\
& austragmites & \multirow{2}{*}{ austris } & 540,0 & 255,3 \\
& & 541,4 & 254,3 \\
\hline \multirow{2}{*}{ Sample 4 } & \multirow{2}{*}{ Phragmites } & \multirow{2}{*}{60} & 538,5 & 249,5 \\
& australis & & 537,0 & 249,1 \\
& & & 537,2 & 247,9 \\
\hline
\end{tabular}

In table 2, the values corresponding to the analyzes performed to the water treatment with the Phragmites australis aquatic plant are recorded, where the standard sample is observed in a zero treatment time. For which, there is $542.7 \mathrm{ppm}$ of total hardness and $300.7 \mathrm{ppm}$ of Chlorides, likewise in the lower part a second sample is observed (sample 1) where these contaminated waters have been treated for a period of 15 days, which showed a decrease in hardness between $542.4 \mathrm{ppm} ; 542.1 \mathrm{ppm}$ and $54.3 \mathrm{ppm}$, while the amount of chlorides decreased by $289.0 \mathrm{ppm}$; $288.7 \mathrm{ppm}$ and 287.5, the following samples are sample 2 analyzed after 30 days of treatment, sample 3 analyzed after 45 days and finally sample 4 of the contaminated samples in a 60-day treatment, these samples as observed have had a significant decrease in both the amount of total hardness and the amount of chlorides.

Removal to hardness: \% Removal $=(542,7-537,2) / 542,7 \times 100=1,01 \%$ Removal to $\mathrm{Cl}-: \%$ Removal $=(300,7-247,9) / 300,7 \times 100=17,6 \%$

Table 3. Chlorine concentrations and Hardness as a function of Lemna minor and Phragmites australis plants.

\begin{tabular}{|c|c|c|c|c|}
\hline Sample & Aquatic plant & Time (days) & $\begin{array}{l}\text { Total hardness } \\
\text { (ppm) }\end{array}$ & $\mathrm{Cl}^{-}(\mathrm{ppm})$ \\
\hline Initial & $\begin{array}{l}\text { Phragmites australis y } \\
\text { Lemna minor }\end{array}$ & 0 & 542,7 & 300,7 \\
\hline \multirow{3}{*}{ Sample 1} & \multirow{3}{*}{$\begin{array}{l}\text { Phragmites australis y } \\
\text { Lemna minor }\end{array}$} & \multirow{3}{*}{15} & 540,0 & 287,5 \\
\hline & & & 540,5 & 288,1 \\
\hline & & & 538,4 & 287,7 \\
\hline \multirow{3}{*}{ Sample 2} & \multirow{3}{*}{$\begin{array}{l}\text { Phragmites australis y } \\
\text { Lemna minor }\end{array}$} & \multirow{3}{*}{30} & 531,1 & 268,3 \\
\hline & & & 530,3 & 266,7 \\
\hline & & & 525,0 & 269,2 \\
\hline \multirow{3}{*}{ Sample 3} & \multirow{3}{*}{$\begin{array}{l}\text { Phragmites australis y } \\
\text { Lemna minor }\end{array}$} & \multirow{3}{*}{45} & 529,0 & 254,7 \\
\hline & & & 528,1 & 254,5 \\
\hline & & & 519,0 & 253,8 \\
\hline \multirow{3}{*}{ Sample 4} & \multirow{3}{*}{$\begin{array}{c}\text { Phragmites australis y } \\
\text { Lemna minor }\end{array}$} & \multirow{3}{*}{60} & 490,4 & 232,2 \\
\hline & & & 489,7 & 240,4 \\
\hline & & & 489,5 & 228,9 \\
\hline
\end{tabular}




\section{Journal of Energy \&. Environmental Sciences}

Vol. 4, $\mathbf{N}^{\circ} 2,2020$

Copyright @ 2020, CINCADER.

ISSN 2523-0905

DOI: https://doi.org/10.32829/eesj.v4i2.199

Table 3 shows the values of the analysis carried out on polluted well waters subjected to treatments with aquatic plants such as Lemna minor and Phragmites australis, where it is observed that the contamination is above the MPL in hardness and $\mathrm{Cl}$-, starting by the analysis performed on the initial sample showing $542.7 \mathrm{ppm}$ of total hardness above the maximum allowable and 300.7 ppm of $\mathrm{Cl}$-. After 15 days of subjecting the contaminated water to the two aforementioned aquatic plants, the hardness decreased in the following concentrations 540.0ppm; $540.5 \mathrm{ppm}$ and $538.4 \mathrm{ppm}$, likewise, chloride concentrations decreased, obtaining figures of $287.5 ; 288.1 ; 287.7$ respectively, after 30 days from the initial process, the hardness concentrations decrease having the following values: $531.1 \mathrm{ppm} ;$; 530.3ppm and 525.0ppm and chloride concentrations also decrease to 268.3ppm; 266.7ppm and 269.2ppm, in this way the decrease is observed as we increase the number of treatment days such as sample 03 of 45 days and sample 4 of 60 days of exposure to water contaminated with aquatic plants.

Removal to hardness: \% Removal $=(542,7-489,5) / 542,7 \times 100=9,8 \%$

Removal to Cl-: \% Removal $=(300,7-228,9) / 300,7 \times 100=3,9 \%$

Table 4. Comparison of the results obtained after treating the well water with the water MPL.

\begin{tabular}{rrr}
\hline Evaluated parameters & End results & $\begin{array}{l}\text { MPL } \\
\text { water }\end{array}$ \\
\hline Hardness $(\mathrm{ppm})$ & 489,5 & 500 \\
Chlorides(ppm) & 228,9 & 250 \\
\hline
\end{tabular}

Table 4 shows the final influence obtained from the Lemna minor and Phragmites australis aquatic plants in the contaminated water from the Huanchaco wells, obtaining 489.5 ppm of decrease in hardness in 60 days and 228.9 ppm of decrease in amount of chlorides which are already below the MPL. 
Vol. 4, $\mathrm{N}^{\circ} 2,2020$

\section{Journal of Energy \&
nvironmental Sciences \\ Journal of Energy \&
Environmental Sciences}

Copyright @ 2020, CINCADER.

ISSN 2523-0905

DOI: https://doi.org/10.32829/eesj.v4i2.199
A publication of

\section{CINCADER}

Centre of Research and Training for

Regional Development

Online at www.journals.cincader.org

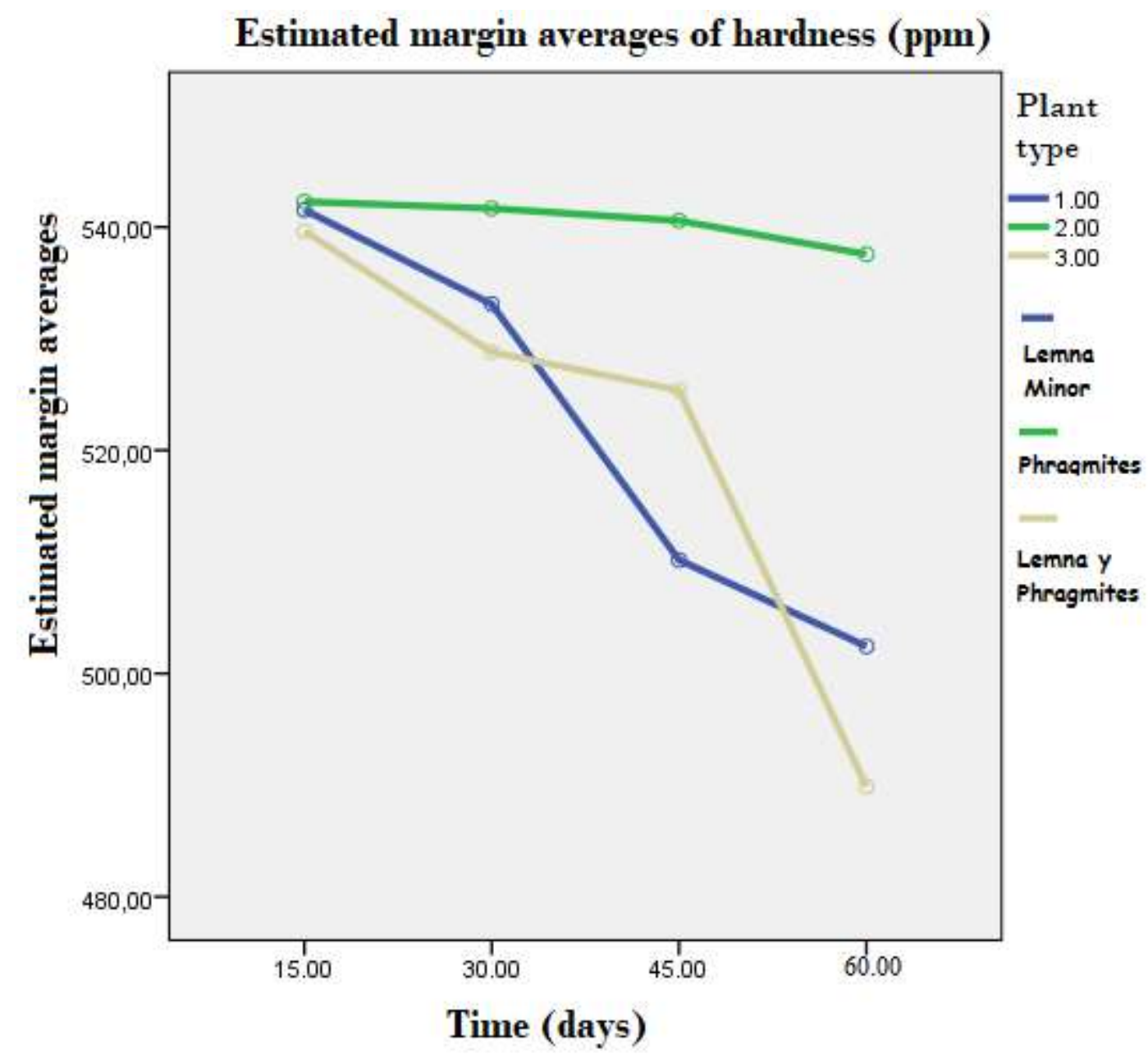

Figure 1. Behavior of the decrease in hardness of the Huanchaquito well water with the aquatic plants Lemna minor and Phragmites australis

In figure 1, the three trends of decrease in total hardness in contaminated waters are observed and as can be seen, the beige line marks the best decrease represents the influence of the two aquatic plants together and the green line (Phragmites australis) represents the smallest decrease in hardness in polluted waters. 


\section{Journal of Energy \&. Environmental Sciences}

Vol. 4, $\mathrm{N}^{\circ} 2,2020$

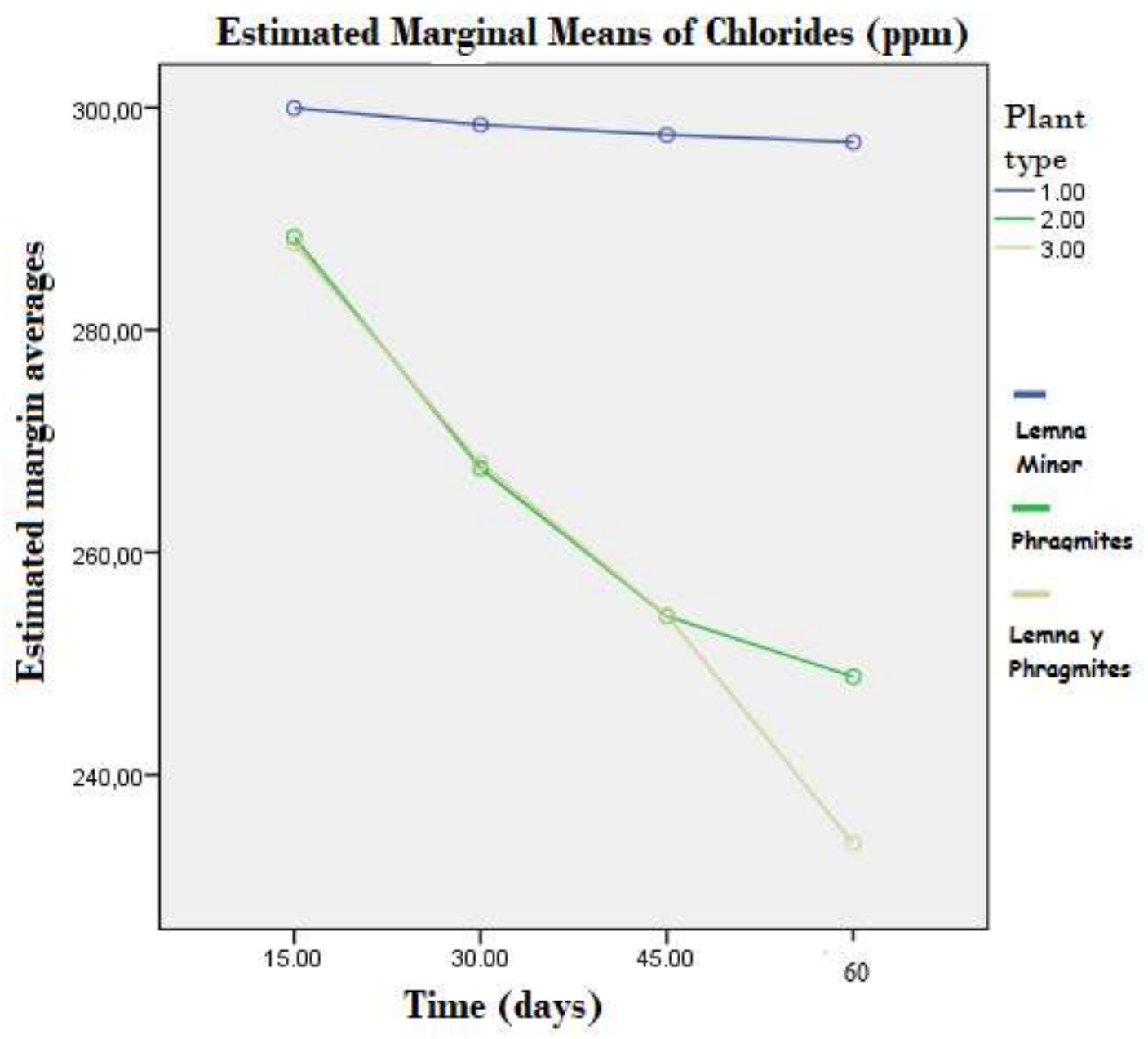

Figure 2. Decrease in the amount of chlorides in the waters of Huanchaquito wells with the Lemna minor and Phragmites australis plants

Figure 2 shows that the beige line that corresponds to the two aquatic plants Phragmites australis and Lemna minor has better performance in reducing chlorine concentrations, unlike the Lemna represented by the blue color, which decreases less chloride concentration.

With these results obtained in table 3 it is observed that the presence of these two plants decreases the amount of chlorides and hardness with greater intensity, decreasing the total hardness in 50 days until reaching $489.5 p p m$ and $228.9 p p m$ amount of chlorides reaching the MPL that establishes Supreme Decree No. 015-2015-mINAm.

If we compare these three experiments in Figure 1 with only the Lemna minor, it decreases until almost reaching the maximum permissible limits, unlike when the two aquatic plants act together, the decrease in total hardness decreases until it reaches the range of MPL below 500ppm contemplated in Peruvian law.

If figure 2 is analyzed, the decrease is equal between the well water exposed only to the aquatic plants Phragmites vs Lemna minor plus Phragmites up to 45 days with a range of 253ppm, this 


\section{Journal of Energy \&. Environmental Sciences}

Vol. 4, $\mathbf{N}^{\circ} 2,2020$

is where it is observed that the two plants together reach decrease the hardness to approximately 230ppm in 50 days, reaching the MPL range.

\section{Conclusions}

According to the results obtained by authors, it can be concluded that:

- It was possible to reduce the hardness and quantity of chlorides present in the well waters of the Huanchaquito-Trujillo district using Lemna minor (Lentil water) and Phragmites australis (Common reed) in artificial media at laboratory level to improve the quality of these waters.

- The Total Hardness of 542.7ppm and 300.7ppm Amount of chlorides present in the well waters of the Huanchaquito-Trujillo district was determined.

- The aquatic plants Phragmites australis and Lena Minor were conditioned in artificial wetlands at the laboratory level.

- The removal percentage was determined for the parameters of hardness and amount of chlorides, the highest percentages in hardness being $9.8 \%$ and $17.6 \%$ of chlorides present in the waters of the wells of Huanchaquito-Alto, Trujillo-La Libertad.

- The decrease in hardness is much faster with the two plants together than with only Lemna minor and that the decrease in Chlorides is much more accelerated with the presence of these two plants than with only Phragmites australis. Likewise, it is stated that Lemna minor alone does not have much effect in reducing Chlorides, as well as Phragmites australis in reducing hardness.

\section{Acknowledgments}

A very special thanks to the Laboratory of Materials - Chemistry II of the School of Materials Engineering from Universidad Nacional de Trujillo for the facilities provided for the development of this research.

\section{References}

Arias, I.,\& Brix, H. 2003, Humedales artificiales para el tratamiento de aguas residuales. Ciencia e Ingeniería Neogranadina, 13, 17-24.

Arroyave, M. 2004, Lenteja de agua (Lemna minor): una planta acuática promisoria. Escuela de Ingeniería de Antioquía, num.1 pag.33-38

Bushmann,P. 2001, Phragmites australis: Control y Efectos sobre la Biodiversidad en los Humedales de Agua Dulce. Restoration Ecology, 1,issue1, 49-59.

Brito,P.,\& Pinheiro,T. 2013, Micro - escala partición elemental en los tejidos de la planta acuática Lemna minor $\mathrm{L}$. expuesto al agua de drenaje carretera. Beam Interactions with Materials and Atoms, 13, 150-153.

Cupe, E.D.,\& Portocarrero, C.J. 2009. Evaluación de la eficiencia de plantas acuáticas flotantes Lemna minor (Lenteja de agua), Eichhorna Crassipes(Jacinto de agua) y Pistia Stratoides (Lechuga de agua), para el tratamiento de aguas residuales domésticas (Thesis).Universidad Nacional de Ingeniería. Lima.

Escutia, Y. 2012, Dinámica de Phragmites australis en respuesta a la adición de fósforo y nitrógeno en humedales experimentales. Botanical Sciences, 90, 35-60.

Martelo J. 2012, Micrófitas flotantes en el tratamiento de aguas residuales. Ingeniería y Ciencia, 8, 221-243.

Mogollón, M. 2005. Caracterización fisicoquímica de los humedales artificiales. (Thesis). Universidad Industria de Pamplona, Norte de Santander.

Serna, JP.,\& Casas, J.C. 2012, Respirometría de Phragmites australis en presencia de materia orgánica disuelta y el xenobiótico clorotalonilo. . E.I.A, 18, 195-208. 


\section{Journal of Energy \&. Environmental Sciences}

Vol. 4, $\mathbf{N}^{\circ} 2,2020$

Copyright @ 2020, CINCADER.

ISSN 2523-0905

DOI: https://doi.org/10.32829/eesj.v4i2.199

Menéndez Valderrey, J. L. 2005, Phragmites australis. 22-07-2016, sitio web:

http://www.asturnatura.com/especie/phragmites-australis.html

Montano, J.J.,\& Sandoval, M. 2005, Recientes aplicaciones de la depuración de aguas residuales con plantas acuáticas. Theoria, 14(1), 17-25.

Ordoñez Gálvez, J.J. 2011, Aguas subterraneas-acuíferos. Global Water partnership, 15 -072016 ;2(85), http://www.gwp.org/global/gwpam files/publicaciones/varios/aguas subterraneas.pdf

Rodríguez. R. 2010, Tratamiento de Aguas de descargas industriales y domésticas.UNESCO. 15.13-12-16.

Rodríguez, S. 2010. Estudio sobre la dureza del agua. Especialización y Maestría en Ingeniería Ambiental. Universidad Tecnológica Nacional.

Skoog D. \& West, D.,\& Holler F. 1995. Química Analítica. México: Graw Hill.

Topal, A. 2015, La absorción de la tetraciclina y la degradación de productos por Phragmites australis cultivados en la corriente que llevan efluente secundario. Ecological Engineering, 79, 80-85. 